\title{
Challenging Hate Speech: Incitement to Hatred on Grounds of Sexual Orientation in England, Wales and Northern Ireland
}

\author{
Kay Goodall \\ Senior Lecturer in Law and Director of Research, School of Law, University of Stirling
}

Kay Goodall is Senior Lecturer in Law and Director of Research at the School of Law, University of Stirling. She specialises in statutory interpretation, anti-discrimination law and hate crime. With Ian McLeod, she is co-editor of forthcoming editions of Bennion's Statutory Interpretation. She has carried out empirical research in several areas, in particular the policing of crimes involving violence or racism.

Room 41, Airthrey Castle, School of Law, University of Stirling, Stirling FK9 4LA, United Kingdom.

E-mail: k.e.goodall@stir.ac.uk

\begin{abstract}
In England and Wales (in 2008) and Northern Ireland (in 2004) legislation has been

enacted to render it a criminal offence to incite hatred based on sexual orientation. This paper examines the relevant pieces of legislation and considers whether they can be kept sufficiently narrow in operation to protect one's freedom of expression. The paper also addresses criticism of such legislation, notably by Eric Heinze, based on arguments on equal protection and cause and effect. It concludes that in the British context, narrowly drafted legislation may have a useful, if marginal, impact and will not necessarily lead to the immense restrictions on freedom of expression that Heinze fears. Nor, however, will the legislation be likely to achieve radical social change while other powerful sources of discriminatory discourse remain uncontrolled.
\end{abstract}

Keywords: incitement to hatred; sexual orientation; criminal law; hate speech; United Kingdom

\section{Introduction}

Less than half a century ago, consensual sex in private between adult males was a crime in the United Kingdom. If we read now the parliamentary records from that time, it is striking how supporters of reform sounded like today's persecutors. In the first of several debates on the famous Wolfenden Report, ${ }^{1}$ the mover, Kenneth Robinson, Member of Parliament, remarked:

I have no wish to suggest that I regard homosexuality as a desirable way of life. It is in my view undesirable for reasons which I will tell the House. It is undesirable because it leads so often to unhappiness, to loneliness and to frustration, because it entails in many cases heavy burdens of guilt and shame on those affected by it and because it seldom provides a basis for a stable 
emotional relationship. It may also possibly be undesirable on moral grounds because it is a sin, but these are matters on which I am not competent to pass judgment. Surely all this suggests that these unfortunate people deserve our compassion rather than our contempt... ${ }^{2}$

Another supporter, Antony Greenwood, Member of Parliament, noted:

Tonight, we have had various estimates of the number of homosexuals in the country. Obviously, it is difficult for any of us to be positive about it. The lowest estimate which I have been able to find is 500,000, approximately the population of the City of Leeds. The highest estimate I have found is that they are nearly as numerous as the population of Wales. ${ }^{3}$

In 1960 - even with the growing support of broadsheet editors and moderate clergymen - it was a brave decision to speak in favour of the motion. Today, it is opponents of equality who regard themselves the brave ones to speak out. The arguments they use, from accusations of paedophilic tendencies ${ }^{4}$ to the description of same-sex sexual orientation as a sin and an abomination, ${ }^{5}$ were however used almost fifty years ago. The difference now is that a bundle of sexual minority rights has been achieved. British society has changed so spectacularly that, in 2008, Stonewall and other campaigners successfully persuaded Parliament to make it a crime in England and Wales to incite hatred against any person based on his or her actual or perceived sexual orientation.

In this paper I examine this new law and its Northern Irish counterpart enacted in 2004 and ask whether this is the right direction for us to take. In particular, I consider the cogent arguments of Eric Heinze against sexual orientation-based hate speech bans. I conclude, with some reservations, that the legislation was the correct course to take.

\section{Prior developments}

There has been a whirlwind of decriminalisation and equality legislation in the UK in the last decade pertaining to sexual minorities. The ages of consent for different-sex and male/male sexual conduct are now finally equal; ${ }^{6}$ criminal laws governing sexual behaviour in England and Wales no longer distinguish between different-sex and male/male participants; ${ }^{7}$ civil partnership, albeit not marriage, ${ }^{8}$ has been enabled; ${ }^{9}$ adoption by same-sex couples has been made possible; ${ }^{10}$ and a person may seek redress if he or she suffers sexual orientation-based discrimination in some areas of employment and provision of goods and services. ${ }^{11}$ Once, consensual male/male sexual activity was a criminal matter; now the battle against homophobic crime is an official priority for the UK police forces. ${ }^{12}$ Offences found to have a homophobic element are more severely punished. ${ }^{13}$ These are only some of the more important developments. Policy too is changing, gradually taking account of the rights even of sexual minority children:

if nothing else, surely realising that he ought to have been using the word we instead of always just that same cross, worn-out I in his angry mutterings would have helped... He cannot account for himself; he cannot describe what he sees. ${ }^{14}$

In Neil Bartlett's poignant tale set in London in 1967, the protagonist toils to identify what he is feeling in a society in which he has never heard of homosexuality. Now, guidance to most schools issued by the Department for Children, Schools and Families requires that they provide sex education 'relevant' and 'sensitive' to the needs of all children, and that they are 
able to deal with homophobic bullying. ${ }^{15}$ As we will see, the modern UK is still far from being a society in which it is entirely safe to express alternative sexual orientations. Nevertheless, it has come far. It is in this context that we should take a closer look at the new law.

\section{UK laws concerning incitement to hatred on grounds of sexual orientation}

Incitement to hatred on grounds of sexual orientation will constitute a criminal offence ${ }^{16}$ in England and Wales ${ }^{17}$ - not Scotland - when the relevant legislative provisions amending Part 3A of the Public Order Act 1986 are brought into force. ${ }^{18}$ It has been an offence in Northern Ireland since 2004 under Part 3 of the Public Order (Northern Ireland) Order 1987; ${ }^{19}$ indeed the Northern Irish legislation is considerably wider than that applicable in England and Wales, although no prosecutions appear to have been brought so far. ${ }^{20}$ I will not discuss Scots law in this paper because there is as yet no corresponding legislation in the Scottish legal system. There is, however, potential for an interesting debate about the extent to which the flexibility of Scots common law could allow a conviction for similar activities.

The provisions for England and Wales in Part 3A cover 'threatening' activities intended to stir up hatred against a group of persons because of their sexual orientation. This could be in the form of spoken words or behaviour or written material or a recording. Displaying material or publishing or distributing written material is an offence, as is distributing, showing or playing a recording. The offence can also (with some exclusions) include performing a play in public, broadcasting a programme or including it in a programme service, or possessing such material with the intention of broadcasting it. The offence can be committed in public or in private, but can only take place within a dwelling if the offending words or behaviour were heard or seen outside the dwelling and were intended to be heard or seen. It is essentially, then, a public order offence.

Sometimes commentators have described the offence as 'homophobic incitement', but Part 3A in fact covers persons of any sexual orientation, including heterosexual (although it does not make specific provision for those who are transgender ${ }^{21}$ ). Section 29AB refers to 'hatred against a group of persons defined by reference to sexual orientation (whether towards persons of the same sex, the opposite sex or both)'. There is no definition of sexual orientation in the Northern Irish Part 3. (One interesting question is whether the English Part 3A excludes asexuality (absence of sexual attraction ${ }^{22}$ ).

What is important is that the offence focuses on hatred directed against a group, rather than hatred targeting individuals. Another key element is the audience, which does not necessarily include the victim, but is rather a separate audience who can be stirred up (hate speech delivered directly at the victim can be usually covered within the ordinary criminal ${ }^{l a w^{23}}{ }^{2}$. What is important too is that there need not be an aim to incite a crime. Advocating violence or other criminal action is already covered by the law. ${ }^{24}$ Rather, the offence consists of an incitement to hatred, which is not otherwise criminal behaviour. It was modelled very closely on the existing English provisions on incitement to hatred on grounds of religion, and as we will see, both are worded extremely narrowly. ${ }^{25}$

There are now three areas covered by incitement to hatred legislation in England and Wales: race, religion, and sexual orientation. The oldest is that which covers incitement to racial hatred. The classic example of an incitement to hatred offence in the UK has been a leaflet through the ordinary public's doors or a speaker at a meeting of a racist group, deliberately stirring up the intended audience with provocative, hate-filled statements about an ethnic minority. Any prosecution of all incitement to hatred offences must first be approved by the Attorney General. ${ }^{26}$ The early convictions under the first specific offence (incitement to racial hatred, created by section 6 of the Race Relations Act 1965) involved extreme language and the ringleaders and active members of openly racist organisations. ${ }^{27}$ 
This was how Parliament had intended the legislation to be used - for the most brazen activities. ${ }^{28}$ Indeed, as the first version of the offence required proof of specific intent, it was often difficult to secure a conviction.

Part 3 of the 1987 Northern Irish Order was drafted much like the English Part 3A. It covers the same basic offences in similar wording, but it also goes much further. First, it does not necessarily require specific intent: it extends to acts that are likely to stir up hatred; 'likely', in this area of law, is to be objectively assessed in the light of all the circumstances. ${ }^{29}$ Second, it also covers acts that 'arouse fear'. Third, it extends not just to threatening words or behaviour, but also to those which are abusive or insulting.

The aim of these sorts of legislation is to fill a perceived gap in the law. In most circumstances, those who stir up hatred are likely to commit an offence, such as when they abuse an identifiable individual, or when they incite others to commit a criminal act. Inciting others to hatred alone, however, (rather than inciting them to commit an offence) is usually not unlawful except where it has been specifically provided for by statute. When the Bill that contained the amended Part 3A was introduced to Parliament, Ben Summerskill of Stonewall, a non-governmental organisation for sexual minority causes in the UK, produced evidence to the House of Commons Bill Committee that cited popular reggae lyrics that exhorted listeners to kill gay men and lesbians (these could however, depending on context, amount to incitement to violence or to murder, which would be an offence). He also produced evidence of British National Party leaflets that explicitly linked paedophilic murders and homosexuality. When asked whether there was anything to suggest that such material had led to an increase in violence, he drew attention to the possibility of a link by citing Crown Office statistics showing a 167 per cent rise over the two preceding years in convictions for crimes aggravated on grounds of sexual orientation. ${ }^{30}$ Such links do not prove causation but they appear to have been sufficient for the Bill to succeed.

Neither statute provides a detailed explanation of what 'hatred' or 'incitement' is to mean (other than a list of the groups to which they are to apply), nor does the Northern Irish Part 3 define 'arousing fear', 'abuse', or 'insult'. It is likely that such words will be seen as 'ordinary' words and therefore a matter for the court of first instance. ${ }^{31}$ Prior case law may be relevant, although in the case of the English Part 3A, the fact that it is a separate Part to the Public Order Act, rather than a simple amendment of the existing law on racial hatred, makes previous decisions less persuasive than they would otherwise have been.

The English Part 3A does, however, contain a saving ${ }^{32}$ on freedom of expression (section 29JA), which states:

In this Part, for the avoidance of doubt, the discussion or criticism of sexual conduct or practices or the urging of persons to refrain from or modify such conduct or practices shall not be taken of itself to be threatening or intended to stir up hatred.

This section was neither originally included in the provisions proposed by the government nor thought necessary by the Parliamentary Joint Committee on Human Rights. ${ }^{33}$ It was inserted by the House of Lords at the eleventh hour. They had done the same thing two years before when they forced through an amendment to religious hatred provisions to include a similar provision. ${ }^{34}$

The sexual orientation hatred provision is less emphatic than its religious hatred counterpart, which provides that '[n]othing in this Part shall be read or given effect in a way which prohibits or restricts discussion, criticism or expressions of antipathy, dislike, ridicule, insult or abuse of particular religions [etc.]. ${ }^{35}$ The concern among Members of Parliament and the media about the religious hatred provisions was that they would discourage robust 
criticism and comic mockery of religious practices. The comedian Rowan Atkinson was given a great deal of media attention for his campaign over several years about the chilling potential of such legislation. ${ }^{36}$ Less media time was given to concerns about the sexual orientation hatred provisions - and the main thrust of these was simply that the provisions would discourage criticism by those with religious beliefs. Presumably, those moving the amendment creating the second saving did not therefore regard it necessary to emphasise the continuing right of comedians to mock gay men and lesbians.

However, the express protection was not strictly necessary. This is because freedom of expression is already implicit as an aid to interpreting all British legislation. Any British statute must insofar as it is possible to do so be construed in a manner compatible with the Human Rights Act 1998. ${ }^{37}$ Courts must take account of the relevant jurisprudence under the European Convention on Human Rights (hereinafter referred to as ECHR or the Convention). ${ }^{38}$ The Human Rights Act requires that particular regard be had to the importance of the freedom of expression embodied in Article 10 of the Convention. ${ }^{39}$ Section 13 of the Human Rights Act similarly lays emphasis on upholding freedoms of thought, conscience and religion in accordance with Article 9 of the Convention. There are other kinds of protection under the Human Rights Act. Under section 19, Ministers introducing a government Bill to Parliament must make a statement that in their view the Bill is compatible with the Convention rights listed in the Act. ${ }^{40}$ All public authorities must also, under section 6 , act compatibly with those Convention rights unless primary legislation expressly requires otherwise. This places a duty on the police and prosecution services to take human rights into account when investigating cases and deciding whether to initiate a prosecution.

It was therefore - as a matter of UK statutory interpretation principles - unnecessary to add the saving. Also, superfluous words risk making it harder for judges to interpret the law. ${ }^{41}$ There is, however, a reasonable argument that since one saving already exists for the religious hatred provisions, inserting another clarifies the legal position for those who are not familiar with the principles of statutory interpretation. Both may deter overzealous policing. They may also help protect against the effects of malicious or misinformed exaggeration of the extent of the law. ${ }^{42}$

\section{Consistency and analogical extensions of human rights norms}

Campaigners relied on what Heinze calls 'cumulative jurisprudence' to achieve the revision of Part 3A. They argued that it was logical to extend the established categories of the incitement laws (racial and religious) to include hatred on grounds of sexual orientation. Heinze defines cumulative jurisprudence as 'a systematic application of general human rights norms to categories of persons not expressly named or intended in leading human rights instruments'. ${ }^{43}$ Here, the argument was that the experience of hate crime and incitement to hatred suffered by sexual minorities was similar to that experienced by ethnic and religious minorities on ethnic and religious grounds. With demonstrated evidence of this hatred towards individuals, and towards sexual minorities as a group, it would be equitable to extend the law on racial and religious hatred to cover sexual minorities.

Stonewall has successfully used this strategy before: indeed it has been their focused approach to campaigning for one incremental advance at a time which has been one of the organisation's most significant tactics in the $21^{\text {st }}$ century, and which has attracted it considerable respect. The tactic has helped bring about some radical changes in law for sexual minorities in the UK, and it is an approach that, in general, Heinze supports. He has maintained that developments in sexual minorities law have been justified on a 'Principle of Extant Rights': they are necessary extensions of existing norms, because the differences between the existing norms and the proposed new one cannot be distinguished in any ethically relevant way (in the context of the surrounding norms of that particular society or 
international social order) in the light of the task the rights instrument is being asked to perform.

Obviously, this argument from indistinguishability is contextual and relative. There are legal orders in which societal norms (such as a constitution based on a moral principle of the inseparability of law and a governing state religion) could cast sexual orientation as a legally relevant ground justifying extensive discrimination. The human rights instruments Heinze considers here, however, have developed in a historical context in which religion the only powerful current ethical framework in Western states which holds sexual orientation to be a relevant factor by which to make fundamental judgments about the worth of individuals - has been increasingly irrelevant as a ground on which to interpret the key norms of those instruments. (Individual states may, however, uphold religious norms within the discretion permitted within their margins of appreciation). ${ }^{44}$ To maintain a legal distinction that includes some victim groups but not others whose plight is ethically similar would therefore render the existing law capricious.

Heinze argues, however, that sexual orientation-based hate speech bans should be regarded differently. In his view, it is not appropriate to extend the law by deriving legitimacy in this way. The reason behind this is the consequences of providing fully equal protection.

Heinze takes the radical view that hate speech bans are inconsistent because they are seriously incomplete. His argument here is not that extending the law to sexual minorities would logically be a step too far. Rather, it is that it would not be enough. Whenever a group is systematically disadvantaged by discrimination it is entitled to the assistance of the law. Why draw the line at sexual minorities when there is such widespread verbal abuse directed at elderly and disabled persons? Better, he argues, that there be no hate speech bans, which are a threat to freedom of expression than that the legitimacy of human rights law be undermined by fragmentary developments.

During the parliamentary debate on amending the English Part 3A, Heinze's views were echoed by Gareth Crossman, the policy director of Liberty (the most prominent human rights campaigning body in the UK). Crossman argued that there was 'no logical reason' for creating an incitement law protecting on some grounds but not on the grounds of sex or disability. He suggested that new offences in this area seemed to develop in response to 'those who lobby most effectively to introduce that offence', adding that:

If we are determining that some areas are suitable for that to be an offence, then unless you can show a logical reason why you should not extend it to any other area where somebody could be discriminated against, then it has to be piecemeal and slapdash. Let me make this absolutely clear. I am not saying please let me make this absolutely clear - and nor is Liberty saying, 'Do away with all incitement to hate law. Do away with all speech offences.' What we are saying is that the way that the law is developing at the moment is undesirable. ${ }^{45}$

Equally, however, Crossman expressed concern about the proportionality of creating a generic offence of incitement to hatred.

Certainly, it is a fundamental value of human rights law that everyone is entitled to equal protection under the law. Indeed, this is the heart of Protocol 12 to the ECHR, which requires that all rights 'set forth by law' be secured without discrimination. They must be made available to everyone without discriminating between persons unless there is reasonable and objective justification for doing so. The official Explanatory Report for the Protocol observes that Article 1 (the general prohibition of discrimination principle) 
is not intended to impose a general positive obligation on the Parties to take measures to prevent or remedy all instances of discrimination in relations between private persons. ... On the other hand, it cannot be totally excluded that the duty to 'secure' under the first paragraph of Article 1 might entail positive obligations. For example, this question could arise if there is a clear lacuna in domestic law protection from discrimination. ... Nonetheless, the extent of any positive obligations flowing from Article 1 is likely to be limited. ${ }^{46}$

Thus, if there is differential treatment in the enjoyment of a right already set forth in national law, such as under the protection offered by incitement offences, this might amount to a breach of Protocol 12. The Protocol builds on and extends the limited antidiscrimination principle in Article 14. The UK has not yet ratified it, ${ }^{47}$ but its adoption by the Council of Europe buttresses the argument for equality which Heinze makes.

There is an argument against Heinze here, though, which is that it would be justifiable to draw a line where the characteristics of the excluded groups make it in some way too difficult and unwieldy in practice for a revised law to operate successfully (i.e., where there is objective and reasonable justification to differentiate). It has in practice been more difficult to define disability for legal purposes than 'race' or religion or sexual orientation have been and much harder to work out what would be reasonable accommodation to what can be a genuine and relevant difference. ${ }^{48}$ But disability is no more a relevant reason for stirring up hatred than 'race', religion or sexual orientation is. And in any case the ingenuity of modern human rights developments such as fourth generation human rights that create anticipatory duties $^{49}$ should allow us to put this objection aside for now and consider Heinze's argument more fully. It forces our attention to the very heart of a niggling uncertainty that I suspect has stirred in the thoughts of any fair-minded jurist who follows the developments in antidiscrimination law.

An ad hoc answer, which would enable imperfect but necessary new laws to be enacted, is that the law has focused on those groups which can be shown to have suffered the deepest systematic discrimination over a long period of time in that state or social order. There is certainly good support for this argument. However, it is clearly not the whole or only explanation. Anti-discrimination law of all kinds has been enacted not only on the grounds of just desserts, but also where elite political opinion has been swung in favour of a group, often because of a calamitous event. In the UK we only need think of the legal changes brought about by the Race Relations (Amendment) Act 2000 after immense publicity given to a critical report that (eventually) followed the murder of young black student Stephen Lawrence. ${ }^{50}$ Another precipitating factor is the successful mobilising of lobbying activity by effective campaign groups. Therefore, although it may in fact have been the most deserving social groups who have benefited from these events and activities, it is not necessarily so. Indeed, the persistence of disadvantage on the grounds of social class in the UK, most convincingly demonstrated by researchers such as Goldthorpe, ${ }^{51}$ makes it clear that there remain large groups of deserving individuals who are silently excluded from the full benefits of current antidiscrimination law.

Furthermore, the law need not protect only the most needy. It could protect all who suffer significant disadvantage to the extent that this could legitimately be described as systematic, or, if not systematic, at least significant in the likely life course of an individual. It might well be that there is a line that should be drawn where the benefit to society is overall reduced by the enactment of new law, because of the further complexity added to the legal regime when weighed against a sufficiently slight benefit to a group. But the position of 
that line needs to be identified by rigorous research, not implicitly assumed as at present. Heinze's argument is open to criticism, but we have yet to muster sufficient evidence to decide whether it is wrong, so debate should be had on whether British laws deal with the appropriate range of concerns.

\section{Implications for freedom of expression}

Heinze develops this point to strengthen his case against hate speech bans. He maintains that although this legal development by analogical extension is ethically justified in other areas of law, it is inappropriate in the case of hate speech bans.

Having argued that protection should extend further, he then invites us to consider the effect on other rights if broader hate speech bans were enacted. If we were fairly to acknowledge the harm caused by hate speech, Heinze insists, we would admit that the damage caused by words such as 'moron' used against those with learning difficulties or 'old bag' used against an elderly woman could cause the same level of harm as does the word 'nigger' used against someone of African or Caribbean origin or 'queer' used against a gay man. In his view, the amount of censorship that would be required for such broad bans is immense, so immense that he does not need to lay out for us what the deleterious effects would be; they are obvious.

Although Heinze's arguments at first glance might seem risible, there is no good reason for that gut reaction. Why should the fierce, contemptuous or mocking use of a derogatory label against a member of a highly vulnerable group not amount to a potentially serious harm? Can we really say with confidence that a political figure, say, publicly describing a person with minor learning difficulties as a moron cannot cause distress, hurt or fear among those with similar disabilities? Can we argue with any certainty that this cannot shore up a form of discourse which constructs such individuals as objects of contempt or dislike?

That Heinze fully recognises this harm is one of the strongest reasons to think very seriously before disagreeing with his decision to oppose hate speech bans. An important question that Heinze does not fully address, however, is whether there is a difference, if not in character, in degree. Equal protection does not require identical treatment if the circumstances are relevantly different. The current UK incitement laws have been enacted where there is some evidence of a history or culture of stirring up hatred against those particular groups. Is there evidence of a comparable culture of stirring up hatred against elderly individuals or those with learning difficulties in the UK?

Referring to a particularly brutal attack on an openly gay man, Heinze observes:

[It cannot be] be argued that Blacks, Jews or sexual minorities have more burdened histories. Nazism showed how physically or mentally disabled persons, along with all the propaganda-hate speech—concerning their threats to Aryan purity and perfection, led them to extermination on the grounds of their putative sub-humanity. Might Chenu's attackers not just as eagerly have assaulted someone mentally or physically disabled, or someone elderly or obese? Can anyone argue that such an attack would not have been motivated by a cultural arsenal stockpiled with age-old barbs of 'idiot', 'spas', 'old bag' and 'fat slob'? It would require a leap of sociological imagination to argue that such an assault would be ignited by a consciousness promoted by hate speech when racially motivated, but not when motivated by stereotypes of mental or physical conditions. ${ }^{52}$ 
It is a powerful point and this problem should be raised as a human rights argument much more often than it has been. Nevertheless, it needs qualification. Stereotyping language takes on a particular virulence in certain contexts. Words such as 'nigger' and 'dirty Jew' have become especially derogatory in Western states because of the particular history associated with, for instance, slavery and the Holocaust (and its predecessors such as the Russian pogroms), and because of the continuing evidence of hatred against those groups. Words such as 'Paki', for instance, clearly fall into the same category of disparaging labelling, but are not - yet - always regarded as equally toxic. ${ }^{53}$ It may well be that the rising level of vilification directed at Muslims may lead to that changing.

When the Bill containing the amended Part 3A for England and Wales was introduced to Parliament, the government justified it by reference to vile examples of bigotry and violence, as noted above. Likewise, the official Explanatory Notes on the amending legislation for Part 3 for Northern Ireland specifically stated that there had been 'increases in recorded incidents involving victims defined by their sexual orientation'. ${ }^{54}$

Homophobic aggression remains a serious problem. According to recent research carried out for Stonewall, one in five gay men and lesbians in Britain stated that they had experienced a homophobic hate crime or incident in the preceding three years. ${ }^{55}$ This is despite the fact that of those polled:

A third of lesbian and gay people alter their behaviour so they are not perceived as being gay specifically to prevent being a victim of crime. This includes not showing affection for their partners in public, dressing differently and avoiding areas where they could be identified as lesbian or gay. ${ }^{56}$

Stonewall rather naughtily called this study the 'Gay British Crime Survey', though it is nothing of the sort. The costly British Crime Survey was close to a miniature census of around 51,000 people, ${ }^{57}$ carefully targeting a representative sample of the population in their homes, whereas Stonewall paid for a YouGov survey of 1,721 people in which self-selected participants answered questions online. However, the British Crime Survey cost millions, and given that it posed no questions covering this sort of hate crime, Stonewall's only option was to pay what it could afford (with some Home Office support) to get somewhat nearer the precious statistics needed to convince government policy-makers. There is however strong supporting evidence in Northern Ireland, where state-funded research found a high and rising level of homophobic crime in some parts of the country. It concluded that '[s]tudies conducted in Northern Ireland have consistently recorded high levels of homophobic attacks, both verbal and physical. ${ }^{58}$

While Heinze rightly cites the history of Nazi persecution of persons with mental disabilities, he has not shown why words such as 'idiot' and 'moron' carry a connotation quite as sinister as 'nigger' and 'Jew' do when used in societies that participated in the slave trade and have been profoundly affected by the mass murder and expulsion of Jews across the world. Nor has he provided evidence of current persecution equal to that suffered by sexual minorities in the UK. Likewise, although there has long been evidence for example of severe domestic abuse carried out against elderly individuals, ${ }^{59}$ there is less evidence of persecution of them as a group. Here, the difference is a question not of character, but of degree. We can relevantly distinguish.

Certainly, it was concluded that the problem of hatred on grounds of disability was sufficiently serious to justify creating a corresponding hate speech ban in Northern Ireland. This seems to have been based, however, on research on persons with learning difficulties carried out in England in 1999 by Mencap, a mental health charity. As a result of this research, and because disability has now been included as a specific statutory ground for 
sentencing enhancement in English law, ${ }^{60}$ Parliament's Northern Ireland Committee report on hate crime had recommended extending the incitement law to include disability. ${ }^{61}$ There appears to have been no other published evidence; another report by the same committee the following year noted that '[h]ate incidents and crimes against the disabled in Northern Ireland are the least well documented by the police and no statistics are available. ${ }^{, 62}$

This is not to say, of course, that disability-based hate crimes are not a real problem, either in Northern Ireland or in England and Wales. Convictions for offences found to be aggravated on the grounds of disability are now monitored, and in 2008 the magazine Disability Now featured a list of horrific examples. ${ }^{63}$ However, evidence of widespread hate crimes against persons with disabilities is not the same as evidence of widespread incitement to hatred against persons with disabilities. The case remains to be made for a change in the English Part 3A to encompass disability. Nevertheless, it may well be that such a case can and soon will be made, and thus Heinze's argument must be taken seriously.

\section{Cause and effect}

Heinze has put forward another compelling argument against hate speech bans. He argues that although there are correlations between hate speech and hate crime, there is no evidence that the speech causes the crime. Without this evidence, hate speech that is less direct than 'fighting words ${ }^{64}$ should not be made subject to the criminal law. The distinction he makes is not based on any facile assumption that hate speech is harmless; he is astutely aware of the ways in which social understandings help construct and reproduce social roles. He is also quick to acknowledge that the speaking of words is an act with consequences, so that (to cite one of his examples) a person is not born a 'nigger', but is made one.

We should not forget that provocative words can have quite tangible results. Every nation has its history of incendiary demagogues who have not specifically advocated violence, but who have roused their audiences to a level of prejudice which has later spilled over into violence. One of the most frustrating and upsetting aspects of researching legal writing on hate speech is having to endure the mealy-mouthed or ignorant, or both, views of commentators who minimise the sting of hate speech whilst claiming that protection should not be available because victim groups are over-sensitive and too easily offended. It has been seriously unhelpful for legal debate that there are two common connotations of offensiveness in this context. One is displeasure - insulted sensibilities -- and the other is harm, likely to cause hurt or fear among vulnerable persons. It may be difficult in legal practice to distinguish the two, but that does not justify ignoring the distinction when discussing why legislation may be needed in the first place. Heinze does not make this mistake; rather he argues only that without sufficient evidence of cause and effect, such speech should not be faced with the full force of the criminal law.

Given however that Heinze accepts that discourse helps to reproduce social roles (it is the labelling that identifies the 'nigger'), it is odd that he steps back from accepting that hate speech can cause hate crime. Perhaps here we could distinguish between a sociological concept of cause in social research and a forensic concept of cause in criminal law. The law in the UK requires evidence of the stirring up to hate, not of the crime that may result, and so causation is not the concern here, which is what worries Heinze. It is extremely difficult to see how one could demonstrate direct causation between, say, the intemperate speeches of a far-right racist politician and an increase in assaults on ethnic minority individuals in his constituency, unless perhaps one of the assailants confessed that they had been motivated to act by the politician's bile. Such examples of course exist, but we are a long way from being able to extrapolate from particular examples to carry out the extraordinarily difficult task of predicting, in all the circumstances, which incidents of hate speech will lead to hate crime. Social sciences can achieve such a thing only in science fiction. 
Nevertheless, research on racist discourse clearly shows general patterns. It shows that the impact of repeated discriminatory speech operates in an insidious way, not simply as individual acts of speech affecting relatively immediate audiences. It can take many forms, of which hate discourse is one, and we know that it can succeed. What we do not know to a high standard of reliability is how to predict when and where particular instances of hate speech will result in hate crime. But we do know that when it is successful, hate discourse acts as strategic persuasion, reinforcing and regenerating prejudiced beliefs and unequal treatment, and promoting - or more accurately, undermining - social solidarity by distinguishing outsiders. ${ }^{65}$ Where is the cut-off point that would prevent this leading to hate crime? The question then is not whether hate speech can lead, directly or indirectly, to hate crime. History shows that it can. It is whether, given our inability to tell what hate speech will achieve this and when in a particular context it will, we should ban any of it.

The difficulty, then, is that this process of causation is indirect and contingent. It is near-impossible to show that one particular act or individual has caused or even is likely to cause this nebulous damage except in the unusual situation where there is compelling evidence such as perpetrator testimony. At best we can look at the wider discourse and context, then try and disentangle causes from correlations more broadly. ${ }^{66}$ The distinction in ECHR jurisprudence between 'concrete expression' ${ }^{67}$ and expression that spreads hatred more indirectly has been underdeveloped, legal debate about this problem being thus unhelpfully vague.

The important question, meanwhile, becomes where it is right in criminal law to draw a line. If the only concern was to prevent the reproduction of hate, we could prohibit even the most subtle forms of discriminatory speech, trampling gaily over freedom of expression. At the other end, if we require that a person can only be regarded as criminally responsible if we can prove to the criminal law's standard of proof, that is, beyond reasonable doubt, that their particular speech will cause their particular audience to commit a particular crime, then it is arguable that even fighting words should be excluded from the criminal law. What proof is there that this angry man whipping up this particular angry crowd will beyond reasonable doubt turn them into a mob? His behaviour may be deeply irresponsible, but we do not know enough about his audience to prove that he needs to be silenced. In reality, almost all of us accept that there should be some limitation of personal liberty in the interests of a public order that we can never be sure will result. This is the terrible problem we face, and Heinze's response, though clarifying the terms of the debate, does not solve it.

\section{Legal threshold and protection of freedom of expression}

This does not dispose of the discussion in the UK, however. What also needs to be considered is the history of prosecutions under incitement to hatred laws, and what threshold needs to be crossed for this offence. How much threat has it posed to the freedom of expression thus far? What risks lie ahead? Heinze observes:

We can safely assume that the films, newspaper or magazine articles, radio and television shows or websites in which terms like 'idiot' and 'moron' appear - the same media that would no longer use 'nigger' or 'queer' in nonironic or non-critical contexts-are innumerable. Remarkably broad censorship of both the media and everyday speech, backed up by legal penalties, would be required. Hate speech bans can only succeed either through enormous measures of censorship or through discriminatory selection of target categories or individuals. ${ }^{68}$ 
It may well be that the non-ironic or non-critical ${ }^{69}$ use of 'nigger', which is regarded as an extraordinarily inflammatory label, would raise the possibility of prosecution for incitement to racial hatred, but there would need to be evidence that the speaker intended to stir up hatred or that in the particular context the word was likely to stir up hatred. The word alone would not constitute grounds for a civil action or criminal prosecution in the UK, though, if uttered by a public figure, it would likely lead to calls for his resignation or dismissal from his post, ${ }^{70}$ and not much more than the use of the word might suffice to provide grounds for a civil action or a prosecution.

The threshold for sexual orientation hatred is higher and it is likely that any future extension of the law to new groups will be similarly restricted. The new English Part 3A applies only to threatening words and behaviour intended to stir up hatred on grounds of sexual orientation. Abuse and insult do not constitute incitement to hatred; it is clear from both the wording of the statute and from parliamentary materials - which are admissible evidence in court - that they are not encompassed in the offence. ${ }^{71}$ Even if the English Part 3A were to be extended to include the grounds of disability, it still would not matter that a person expressed hatred in the form of words such as 'idiot' or 'moron' unless there were something more - an intended threat.

I have argued elsewhere that because the near-identical offence of incitement to religious hatred requires proof of both threat and specific intent (to be construed in the light of the freedom of expression provision) it will be almost unenforceable unless the accused confesses. ${ }^{72}$ Equally, how easy will it be to prove, in the face of a not guilty plea, that words were not just insulting or abusive, but were actually intended to be threatening and furthermore were intended to stir up others to hatred of gay men and lesbians as a group?

The history of racial hatred provisions in the UK - even when they have not required proof of intent - has been that prosecutions have been few and convictions consequently rare. ${ }^{73}$ Similarly-worded legislation in the Republic of Ireland under the Incitement to Hatred Act 1989 (which extends to sexual orientation) appears to have resulted in no convictions on grounds of sexual orientation ${ }^{74}$ - and indeed by 2001 there had only been one conviction on any ground. ${ }^{75}$ There have also been no prosecutions in Northern Ireland for incitement to hatred on grounds of either sexual orientation or disability - despite the wide wording that includes acts intended or likely to stir up hatred or arouse fear. On the other hand, there is no information to indicate whether this is because of a lack of will to prosecute; because the legislation is hard to enforce; because complaints to the police are not forthcoming; or because prosecutors suspect that juries would tend to acquit. ${ }^{76}$ One government report did, however, suggest that the lack of convictions was due to 'problems of definition'. ${ }^{77}$ If so, whatever the criminal justice context, it is a poor day for civil liberties and the fundamental value of legal equality if, instead of legislative clarity, we have prosecutorial restraint. As Lord Bingham observed in the House of Lords decision in $R$. v. K.:

The rule of law is not well served if a crime is defined in terms wide enough to cover conduct which is not regarded as criminal and it is then left to the prosecuting authorities to exercise a blanket discretion not to prosecute to avoid injustice. $^{78}$

\section{Prosecutions in practice}

The law in the UK needs to be understood, then, both in the light of its narrow wording and in the context of prosecutorial practice. Both should worry us. Bailey, Harris, and Jones have argued that one reason for the lack of case law on incitement to racial hatred was that racist literature had been less 'intemperate' than before. ${ }^{79}$ Rumney has mounted a particularly spirited and well-researched defence of the legislation in practice. ${ }^{80}$ But it is notable that for 
many years the practice was to prosecute only relatively severe cases of incitement to hatred - and not always some of those. Powerful interests can deter prosecutions. Geoffrey Bindman, one of the most respected human rights barristers and jurists in the UK, wrote recently of a decision to prosecute The Sun newspaper in 1986 for incitement to racial hatred. The decision was revoked after the paper's fearsome lawyer put pressure on the Attorney General behind the scenes. ${ }^{81}$

The most relentless assaults on some groups in the UK come from the print media. Research in 2008 on news stories about Muslims demonstrated a pattern of misrepresentation in which two-thirds of the 'news hooks' involved terrorism, religious difference or extremism. ${ }^{82}$ The worst offences by the press include publishing inflammatory stories that are nothing more than invention. ${ }^{83}$ The United Nations Committee on the Elimination of Racial Discrimination commented in 2003 that the UK Press Complaints Commission needed to be made 'more effective' in dealing with racial discrimination: ${ }^{84}$ a view the UK Parliamentary Joint Committee on Human Rights supported. ${ }^{85}$ An academic study in 2008 found that the Commission had not upheld a single complaint about discrimination on grounds of race or ethnicity. ${ }^{86}$

It is unlikely, then, that the media targets Heinze identifies would be those who would face prosecution in the UK under a law criminalising incitement to hatred against persons with disability. This becomes clear if we look at the more recent prosecutions for incitement to racial hatred for analogous examples (ignoring for the moment the greater breadth of the racial hatred provisions than would be likely in the new legislation). The prosecutions encompassed such activities as preaching sermons that vilify Jews; ${ }^{87}$ making speeches to supporters stating that Islam sanctions rape; ${ }^{88}$ distributing leaflets alleging that 'Muslims' (which was held to be a codeword for Pakistanis) were 'running amok' and carrying out attacks in parts of Glasgow; ${ }^{89}$ and chanting hate-filled language during a demonstration. ${ }^{90}$ It is outsiders, albeit not ineffective outsiders, who are being prosecuted for perpetrating the offence.

In bleak contrast, there has been no suggestion of prosecuting the Mail for claiming in 2003 that asylum-seekers infected with HIV were placing public health at risk when the parliamentary report from which this story originated had specifically stated that they were not the source of HIV infection from overseas. Worse still, the original report had expressed the view that it was prejudicial media reports that were in fact creating a situation where politicians felt obliged to isolate asylum-seekers, so that an asylum-seeker who did become infected would be less likely to get necessary medical care. ${ }^{91}$

Nor would even a mild reprimand from the Press Complaints Commission seem likely to be forthcoming for the likes of the Mail. Chris Frost notes that in 2000 the Commission failed to find The Sun's bileful language - singled out in examples such as 'scrounging Romanian gypsies' and 'our land is being swamped by a flood of fiddlers' - to be either racist or discriminatory. It appears that the Commission defended its decision on the grounds that the 'opinions' were not directed at individuals. ${ }^{92}$

Heinze posits two options: either hate speech bans exclude some groups discriminatorily or include all and so unacceptably limit free speech. There is a third option, however, which is that they include as many groups as need protection, but serve a primarily symbolic or expressive function, because they are so difficult to make use of. This is the approach the UK seems to be taking. It is open to criticism - particularly if the religious and sexual orientation provisions turn out to be almost unusable - but it does not suggest a high risk of an immense increase in censorship. It needs to be remembered that states parties to the ECHR are required to uphold not only Articles 9 and 10, but also to meet their Article 17 duty not to permit the deprivation of other Convention rights and freedoms. ${ }^{93}$ 


\section{Are the UK laws really 'hate speech bans'?}

It is worth asking whether the English Part 3A and the Northern Irish Part 3 genuinely amount to 'hate speech bans'. On the face of them, both would, particularly the Northern Irish. In his discussion of hate speech bans, Heinze focuses on two examples in international human rights instruments. Article 20(2) of the International Covenant on Civil and Political Rights requires the prohibition of 'advocacy' of specified grounds of 'hatred' that constitute 'incitement to discrimination, hostility or violence'. Article 4 of the International Convention on the Elimination of All Forms of Racial Discrimination requires states parties to prohibit among other things the 'dissemination of ideas based on racial superiority or hatred' and 'incitement to discrimination'. Article 4 is potentially very broad, but Article 20(2) is quite specific. The resemblance between these provisions and the language of the UK legislation is obvious.

There would be two difficulties with referring to the English Part 3A as a hate speech ban, however. First, it is not a ban on hate-filled speech as such - rather it is a ban on speech that seeks to incite others to hate. This is a significantly narrower category. It requires proof of specific intent to stir up others, which places a substantial burden on the prosecution. It also requires evidence of threat, not merely abuse or insult. The threat must be intentional, so it is not enough that abusive behaviour might in effect be threatening - the perpetrator must have intended that it be. Taking all these together, we see for instance that merely referring angrily to 'queers' would be far from enough to constitute an offence.

Second, it tends to focus judicial thought on acts affecting a relatively circumscribed audience, whether that be those in the immediate vicinity or those likely to view a recording or broadcast. Its primary task is to maintain public order, not to tackle aggressive bigotry in whatever form it occurs. Whilst it may be that the Northern Irish provisions have been little used as a matter of political caution, the English legislation is very restrictively drafted.

The English Part 3A, then, does not ban all immoderate expressions of hate, but it does extend further than the classic prohibition of 'fighting words'. It deals not with inciting violence (which is a separate crime), or with inciting hatred against specific individuals (which is again subject to the ordinary criminal law), but with inciting hate against a group (where actual individuals need not be specified). What restricts it are the principles and rules I have discussed above.

This does not justify any complacency. I have argued that the English Part 3A (the religion and sexual orientation hatred provisions) is so narrow as to be almost unusable. The English racial hatred provisions are significantly broader and have for many years been a better example of legislation that is workable and that has not opened floodgates to prosecutions. It should also now be restrained by the freedom of expression provisions of the Human Rights Act 1998. However, decisions have been reached recently both in incitement to hatred law and in other areas of the criminal law which should cause concern. In Hammond v. DPP ${ }^{94}$ an evangelical Christian preacher was in the habit of setting up in a city centre square a large double-sided sign bearing the words 'Stop Immorality', 'Stop Homosexuality' and 'Stop Lesbianism'. This had previously attracted protest. On the occasion in question, members of the public found it distressing and insulting. A group of protesters assaulted Mr Hammond. Police officers asked him to take down the sign and leave but he refused. They then formed the view that he was provoking violence and arrested him for breach of the peace. He was convicted of an offence under section 5 of the Public Order Act 1986, aggravated on grounds of sexual orientation, for displaying an insulting sign within the hearing or sight of a person likely to be caused harassment, alarm or distress thereby. The appellate court held that it was proportionate to restrict his freedoms of expression and of thought, conscience, and religion because it had been open to the lower court to conclude that Hammond had knowingly gone 'beyond legitimate protest' and was provoking violence and 
disorder, which interfered with the rights of others, and that he had failed to demonstrate a defence that his behaviour was reasonable. There was therefore a legitimate aim of preventing disorder and thus a pressing social need for the restriction. Further appeal to the European Court of Human Rights was refused.

The court observed that a 'heckler's veto' was not justifiable, but it is hard to see how someone in Hammond's position could otherwise peacefully express his or her views in the face of persistent unrest. Ironically, in the light of the discussion here, it has been claimed that Hammond suffered from Asperger's syndrome. ${ }^{95}$ If so, an impaired ability to make fine judgments about social situations would have made it harder for Hammond to identify when his actions had gone beyond legitimate protest.

Another question that remains is who the targets of the English Part 3A are. The offence of incitement to racial hatred, as we have seen, has a wider compass than the other incitement offences. There is no freedom of expression saving in the legislation to confine judicial attention, and it can be applied not just where there is intent to stir up hatred, but where this is merely a likely outcome. It covers not just threats, but also abusive and insulting words. I have mentioned above that it has long been used only for dealing with far-right ringleaders and activists of organisations whose core activities promote racial division, but a recent decision has called this into question.

In $R$. v. Saleem, ${ }^{96}$ one of the defendants, Saleem, was convicted of incitement to racial hatred after taking part in a demonstration about the Danish cartoons depicting Mohammed. ${ }^{97}$ Saleem had led chants of, inter alia, 'democracy hypocrisy', 'UK you will pay', 'with your blood' and '7/7 on its way'. Similar chants were led against Denmark, Norway and 'Europe'. For this, he was sentenced to four years' imprisonment (reduced to 30 months on appeal).

What is disturbing about this conviction is, first, the presumption that the hatred likely to be stirred up was racial and, second, the context of the offence. Lord Phillips of Worth Matravers, Lord Chief Justice of England and Wales, delivering the judgment on behalf of the Court of Appeal of England and Wales stated:

The offences with which we are concerned involved a one-off demonstration, mounted at short notice without sophisticated planning. It has been urged on behalf of the appellants that re-publication of the cartoons caused worldwide outrage on the part of Muslims. Peaceful and lawful demonstrations in these circumstances would not have been objectionable. But, as Miss Ezekiel for the Crown pointed out, this demonstration was not lawful and was objectionable. It attracted ultimately a band of some 300 demonstrators, most of whom were young men. We have viewed each of the individual videos prepared for the purpose of the separate trials. Most taking part in the demonstration appeared to be joining readily in chanting the slogans that were led over the amplification. Insofar as this crude chanting and the messages on the placards solicited murder, we do not think that this was likely to persuade those who witnessed the demonstration in central London, or who saw the television broadcasts of it, to resort to killing, although one cannot be sure of the effect that it might have on those already inclined to terrorist activity.

We have been more concerned to consider the likelihood that the appellants' conduct might have stirred up those taking part in the demonstration to acts of violence. The police who were monitoring the demonstration would have been obvious targets, as might have been the Danish Embassy. The Common Serjeant recorded that police officers had assessed the mood as excitable and that it appeared to be being whipped up 
into a frenzy by the speakers. The videos that we have seen did not portray the scene that this had suggested to us. While at times the chanting was loud and enthusiastic, the demeanour of the demonstrators did not appear to be violent or threatening. There was a considerable police presence. The police decided that to intervene might provoke disorder and this evaluation may well have been correct.

Having said this, the demonstration took place only six months after the London bombings of 7 July and, at times, both these, the Madrid bombings and the attack of 9/11 were the subject of approbatory chanting. The exhortations on some of the placards and the subject matter of the chanting were offensive in the extreme. They were a demonstration of and an incitement to racial hatred. This must have been apparent to Saleem and we consider that the Common Serjeant was entitled when sentencing him to proceed on the basis that he intended to produce this result. ${ }^{98}$

The court's presumption that the chants led by Saleem had a racial component was not at all apparent from the court's findings. In the context of the direct participation of the UK and the other named states in invading and occupying one or both of two Islamic countries (lest one forget, Afghanistan and Iraq), the chants could be taken as political rather than racial. To say this is not to downplay the odious violent content - particularly given that it took place only months after a bombing in that very city, which killed 52 victims - but rather to question the racial nature of the content. Supporters of the Irish Republican Army, for instance, were not convicted of incitement to racial hatred for similar seditious activities against the UK government, yet they did not always bother to distinguish between 'British' and 'British government'. The convictions depoliticised the actions of the participants.

It is, of course, hardly unusual for governments - and sometimes, courts - to suppress political activity in times of terrorist violence. The measures that were used to silence even the most mannerly dissent at the height of the conflicts in Northern Ireland were breathtaking. The young and those with short memories would do well to read Larry Grant's discussion of the trial of pacifist Pat Arrowsmith for incitement to disaffection after she distributed leaflets in public informing soldiers on how to leave the army. ${ }^{99}$ The full text of the leaflet is reproduced in Grant's article and it appears, to modern eyes, almost laughably mild and polite. Denial of the political element of violent activism is not unusual either. What is worrying here is the apparent weakness of the justification offered for Saleem's conviction by the court for that particular offence. We are left with the fear that the breadth of the racial hatred legislation which lacks any need for proof of specific intent resulted in an inappropriate decision. The outcome suggests, as Lord Lester, the architect of the revised English Part 3A recently said, that Parliament 'extended the race hate speech provisions very broadly indeed - perhaps too broadly. ${ }^{100}$

Heinze's fears about the consequences of overly broad legislation, then, can be challenged but in the light of Saleem they are not to be casually dismissed. England, Wales and Northern Ireland may have managed to implement incitement to racial hatred legislation that has been of little threat to freedom of expression for many years. Saleem, however, threatens (from the available evidence) to be the harbinger of a new and repressive direction.

The question of how to protect rights and yet preserve a usable form of legislation is nevertheless no easy one. At the moment Members of Parliament and free speech campaigners may be congratulating each other for preventing the incitement to religious and sexual orientation hatred provisions from being so broad that they might threaten a reasonable degree of the freedom of expression. It would be simple to suggest that the incitement to racial hatred provisions should be revised to achieve the same effect. But the 
decision may prove less popular if extremist groups contest the English Part 3A and find that they can design a thousand loathsome ways to escape it.

Little may be achieved, too, if a free hand is left to the daily print media. I carried out a newspaper search for reports and commentaries in UK local and national newspapers on the progress of the Bill to revise Part 3A. The great majority took a negative tone towards the Bill in its original format, contrasting it with 'free speech' which was always implicitly assumed to be achieved by minimum interference rather than by regulation. Most gave some space to arguments in favour of the Bill - but usually not before the last paragraph. A few were neutral in tone; these mostly appeared when the Bill was first announced. Only a handful were predominantly positive, two referring to the Bill 'which faces being blocked' and to 'unbridled free speech'. One turned out to be a Mail piece dealing not with the incitement provisions but with separate Scottish proposals - and which had a twist in the tail, claiming that the proposals were causing a 'fierce backlash' among Scottish Muslims. ${ }^{101}$

The tone of the reports was not as negative as those which had covered the previous incitement to religious hatred proposals. There was also a great deal less hyperbolic rhetoric claiming that everyday critique and humour would be silenced. The underlying implication remained, however, that a group was receiving undeserved special treatment. This problem of a media meta-discourse that undermines groups through subtler attacks is difficult to tackle. $^{102}$

Here there is a surprising but important point to be made about the reporting of prosecutions for incitement to hatred, and it suggests a direction for some interesting research to test it out. It is often argued that such prosecutions give the oxygen of publicity to small, extremist groups. However, the prosecutions are generally reported with considerable distaste for the views of the groups on trial. Far from providing unhealthy publicity, they could be seen as providing some of the few occasions in which the media give significant attention to the deleterious effects of unregulated speech.

\section{Conclusion}

It should be apparent that no consensus on hate speech bans is about to be reached, and so I can only conclude with my own observations. I believe that there is room for restricted (but not unenforceable) incitement law where good evidence shows there is a history of hatred against specific minorities for the law to address. As Rumney points out, some extremist groups are secretive and isolationist, uninterested in dialogue. Incitement to hatred laws have been more successful than many assume in limiting the impact of extremist activities in the UK. ${ }^{103}$

Another necessary element is more intelligent political strategy. Malik describes the amended English Part 3A as 'a welcome sign of the commitment to take a zero tolerance approach to homophobic hate speech' but also emphasises that non-legal solutions are more important because the most serious source of hate speech is mainstream public discourse. ${ }^{104}$ She focuses on abuse of Muslims, but her arguments are applicable more widely. She has also argued that the more useful approach in extremist cases may be informed political engagement with the illiberal groups where the groups are willing to take part, even if in some cases the motives of the groups are at first opportunistic. What must come first, though, is developing more sophisticated principles for debate. ${ }^{105}$

I doubt whether any of this is enough without stronger UK enforcement of sanctions against media abuse of freedoms. Though newspapers and broadcasters like to present themselves as champions of the freedom of expression, most belong to private, profit-seeking corporations and all depend to some extent on audience figures. To pretend otherwise is cant, and their claim to a single noble motive should not be unquestioningly indulged. I have dealt here only with the print media, which occupy a shrinking sector of the market, but the 
bestselling newspapers are still powerful enough to shape public discourse and their excesses need to be controlled.

Finally, we have to consider the contradictory records of successive UK governments themselves. Government policies and communications to the public come with many voices and some have consistently appeased bigoted sentiment. ${ }^{106}$ In a briefing to Parliament for an early and failed attempt to create an offence of incitement to religious hatred, Liberty made the following acid observation:

Liberty is aware of the dangerous rise and promotion of anti-Muslim sentiment and hysteria over the last three years in this country. The Government would be wise to look to their own rhetoric and discriminatory and unjust policies before passing further criminal law. ${ }^{107}$

\section{Acknowledgments}

I am much indebted to Phil C.W. Chan for his generous and tireless efforts in improving the most intricate details of my paper. I would like to express my gratitude for his enthusiasm and professionalism, and his exceptional intellectual commitment to this special double issue. I also wish to thank Eric Heinze and the three anonymous reviewers for their helpful and insightful comments on an earlier version of this paper.

\section{Notes}

\footnotetext{
${ }^{1}$ Wolfenden Committee, Report of the Committee on Homosexual Offences and Prostitution, Cmnd.247 (London: HMSO, 1957): among other things the report recommended decriminalisation in restricted circumstances of some sexual acts between men not below the age of 21 .

${ }^{2}$ HC Deb., col.1454-1455, 29 June 1960.

${ }^{3}$ Ibid., at col.1499.

${ }^{4}$ See the material provided by Ben Summerskill of Stonewall to the Public Bill Committee examining the Criminal Justice and Immigration Bill, HC Deb., col.75, 16 October 2007.

${ }^{5}$ New Northern Ireland Assembly member, Iris Robinson, wife of the Northern Irish First Minister, available at http://news.bbc.co.uk/1/hi/northern ireland/7482263.stm (last accessed at 23 August 2008).

${ }^{6}$ Sexual Offences (Amendment) Act 2000 (c.44), s.1. Note that the age of consent in England, Wales and Scotland is 16 but is 17 in Northern Ireland. A controversial draft Sexual Offences (Northern Ireland) Order 2007 has been proposed to reduce the age of consent in Northern Ireland to 16.

${ }^{7}$ Sexual Offences Act 2003 (c.42), s.140 and Sch.7.

${ }^{8}$ The distinction was widely debated in the UK in academic writing: for a useful introduction, see the special issue of Law and Policy, Vol.26 No.1 (2004). See also the critical discussion by Kristen Walker on the demerits of same-sex marriage: 'The Same-Sex Marriage Debate in Australia', International Journal of Human Rights Special Double Issue: Equality in Asia-Pacific: Reality or a Contradiction in Terms?, Vol.11 Nos.1/2 (2007), p.109.

${ }^{9}$ Civil Partnership Act 2004 (c.33).

${ }^{10}$ It was previously possible for a gay man or lesbian to adopt as an individual but not as part of a same-sex couple. It is a complex area of law, but see in particular the Adoption and Children Act 2002 (c.38), and section 30 of the Adoption and Children (Scotland) Act 2007, asp 4, in
} 
relation to same-sex couples. Consultation has been taking place in Northern Ireland on the possibility of similar legislation.

${ }^{11}$ See, in particular, Employment Equality (Sexual Orientation) Regulations 2003/1661; Equality Act 2006 (c.3); and a forthcoming Single Equality Bill tabled to be introduced to Parliament in 2009.

${ }^{12}$ See, e.g., Hate Crime: Delivering a Quality Service (London: Association of Chief Police Officers and Home Office Police and Partnership Standards Unit, 2005), ch.2.

${ }^{13}$ See Criminal Justice Act 2003 (c.44), s.146; Criminal Justice (Scotland) Act 2003, asp 7, s.74; and Criminal Justice (No.2) (Northern Ireland) Order 2004/1991 (NI 15), Art.2. These provide for enhanced sentencing where it is proved that an offence was aggravated by hostility (in Scotland, 'malice and ill-will') related to sexual orientation.

${ }^{14}$ Neil Bartlett, Skin Lane (London: Serpent's Tail, 2007), pp.204-205 and 250.

${ }^{15}$ United Kingdom Department for Children, Schools and Families, Sex and Relationship Education Guidance, DfEE 0116/2000, at pp.12-13. Note that the guidance covers England, Wales and Northern Ireland only (Scotland deals with these matters separately under the devolution settlement) and does not apply to independent schools; parents may also withdraw their children in state schools from these lessons.

${ }^{16}$ To be precise, the English legislation creates several offences under one umbrella, as does the Northern Irish. For the sake of clarity, though, I will refer to each as if there was a single offence in each jurisdiction.

${ }^{17}$ All references in this paper to 'English law' or 'English Part 3A' also encompass Wales.

${ }^{18}$ See the revised section 29A in Part 3A of the Public Order Act 1986 (c.64), as amended by the Criminal Justice and Immigration Act 2008 (c.4), s.74 and Schs.16 and 28, Part 5. My thanks to Santiago Alonso for correcting my misunderstanding of these.

${ }^{19}$ Part 3 (Articles 8-17) of The Public Order (Northern Ireland) Order 1987 (NI 7), as amended by Article 3 of The Criminal Justice (No.2) (Northern Ireland) Order 2004/1991 (NI 15), which came into force on 28 September 2004.

${ }^{20}$ See statement of Maria Eagle, Parliamentary Under-Secretary of State for Justice, to the House of Commons Public Bills Committee discussing the Criminal Justice and Immigration Bill on 29 November 2007. A LexisNexis search I carried out for this paper also did not uncover any Northern Irish case law.

${ }^{21}$ The United Kingdom Parliamentary Joint Committee on Human Rights noted that evidence so far indicated that the kinds of incidents experienced by transgender individuals tended to be covered by the existing criminal law, and that there was currently no evidence of incitement of hatred against them as a group. It concluded, however, that 'urgent' research should be carried out. Fifteenth Report, March 2008, HMSO, at paras 2.18-2.20.

${ }^{22}$ Thanks to Ian McLeod for raising this point.

${ }^{23}$ See, e.g., sections 4, 4A and 5 of the Public Order Act 1986 (c.64), covering a range of offences involving threatening, abusive or insulting words or behaviour where these are likely or intended to cause harassment, alarm and distress. The Protection from Harassment Act 1997 (c.40) covers an extensive range of behaviours amounting to harassment. Other offences attract enhanced sentencing under several statutory provisions (general and specific) where there is evidence of motivation or demonstrated hostility related to sexual orientation.

${ }^{24}$ This was originally a matter for the common law of incitement to crime: now see Serious Crime Act 2007 (c.27), Part 2, on encouraging or assisting crime, which covers England, Wales and Northern Ireland. Note that conspiring or soliciting to commit murder is covered by section 4 of the Offences Against the Person Act 1861 (c.100).

${ }^{25}$ These are also to be found in Part 3A, and pre-date the amendment.

${ }^{26}$ Where they extend to Scotland - which is the case only with incitement to racial hatred - the equivalent law officer is the Advocate General. 
${ }^{27}$ See the cases discussed in Geoffrey Bindman, 'Incitement to Racial Hatred', New Law Journal (March 1982), p.299.

${ }^{28}$ B.A. Hepple, 'Race Relations Act 1965', Modern Law Review Vol. 29 (1966), p.314.

${ }^{29}$ See discussion in A.T.H. Smith, The Offences Against Public Order (London: Sweet \& Maxwell, 1987), at p.157.

${ }^{30}$ Public Bill Committee examining the Criminal Justice and Immigration Bill, HC Deb, col.75, 16 October 2007.

${ }^{31}$ See the leading case of Brutus v. Cozens [1973] AC 854; see also Smith, note 29 above, at pp.4243 and $151-152$.

${ }^{32}$ Readers from outside the UK may be unfamiliar with the term 'saving'. A saving is a provision 'the intention of which is to narrow the effect of the enactment to which it refers so as to preserve some existing legal rule or right from its operation': F.A.R. Bennion, Bennion on Statutory Interpretation: $A$ Code, $5^{\text {th }}$ ed. (London: Butterworths, 2008), at p.725.

${ }^{33}$ Fifth Report, January 2008, HMSO, at para.1.64: the Committee stated that the provisions as introduced provided in their view 'an appropriate degree of protection for human rights'.

${ }^{34}$ HL Debs, passim, 7 May 2008. On the amendments regarding religious hatred in the original Bill creating Part 3A, see Ivan Hare, 'Crosses, Crescents and Sacred Cows: Criminalising Incitement to Religious Hatred', Public Law [2006], p.520; Kay Goodall, 'Incitement to Religious Hatred: All Talk and No Substance?', Modern Law Review Vol.70 (2007), p.90.

${ }^{35}$ Public Order Act 1986, (c.64), s.29J.

${ }^{36}$ Atkinson had also campaigned against the earlier failed proposals to introduce the offence. A speculative search of LexisNexis Butterworth News on 18 July 2008, covering all UK national and regional newspapers, simply on the search terms 'Rowan Atkinson', 'religious hatred', and 'law', brought up 510 citations. It should be noted that some of these are duplicates, but it remains evident that the press coverage was substantial.

${ }^{37}$ Human Rights Act 1998 (c.42), s.3.

${ }^{38}$ Ibid., s.2.

${ }^{39}$ Ibid., s.12.

${ }^{40}$ These include Articles 2-12 and 14, and Articles 1 to 3 of the First Protocol and Articles 1 and 2 of the Sixth Protocol, as read with Articles 16 to 18 of the Convention: see section 1 and Schedule 1.

${ }^{41}$ As F.A.R. Bennion notes: 'On the presumption that Parliament does nothing in vain, the court must endeavour to give significance to every word of an enactment': Bennion on Statutory Interpretation: $A$ Code, $5^{\text {th }}$ ed. (London: Butterworths, 2008), at p.1157. Surplusage is therefore to be avoided.

${ }^{42}$ Stonewall did not object to the possibility of such a saving being introduced when it was initially posited at the Public Bill Committee examining the Criminal Justice and Immigration Bill, HC Deb, col. 75, 16 October 2007.

${ }^{43}$ Eric Heinze, 'Cumulative Jurisprudence and Human Rights: The Example of Sexual Minorities and Hate Speech', International Journal of Human Rights Special Double Issue: Protection of Sexual Minorities since Stonewall: Progress and Stalemate in Developed and Developing Countries, Vol.13 Nos.2/3 (2009).

${ }^{44}$ The doctrine of margin of appreciation as developed in the jurisprudence of the European Court of Human Rights and associated bodies is a recognition that the Convention is implemented in states with different economic, political and cultural histories and distinctive legal systems. In the area of freedom of expression, the Court discussed this doctrine in Handyside v. United Kingdom (1976) 1 EHRR 737.

${ }^{45}$ Public Bill Committee on the Criminal Justice and Immigration Bill, 18 October 2007, cols.127 and 129-130. 
${ }^{46}$ Protocol No.12 to the Convention for the Protection of Human Rights and Fundamental Freedoms, Explanatory Report, Council of Europe. The justificatory restriction derives from Convention jurisprudence: see Robert Wintemute, 'Filling the Article 14 "Gap": Government Ratification and Judicial Control of Protocol No 12 ECHR', European Human Rights Law Review [2004], p.485.

${ }^{47}$ See also Abdulariz et al. v. United Kingdom, 28 May 1985, Series A, No.94, (1985) 7 EHRR 471, where an applicant was permitted to rely on Protocol 4 which the UK had not ratified.

${ }^{48}$ As regards the UK, see e.g., the informed discussion in David I. Hosking, 'A High Bar for EU Disability Rights', Industrial Law Journal, Vol.36 (2007), p.28.

${ }^{49}$ Sandra Fredman, Discrimination Law (Oxford: Oxford University Press, 2002), ch.6. Such rights focus on broadening the context of institutional responsibility, for instance imposing a positive duty on an organisation requiring it to be proactive in monitoring recruitment and progress of members of disadvantaged groups within the organisation. This can be compared with a more traditional reactive responsibility that only requires organisations to respond to individual allegations of discrimination as they occur.

${ }^{50}$ Sir William Macpherson, The Stephen Lawrence Inquiry, Cmnd.4262-I (London: HMSO, 1999).

${ }^{51}$ J. H. Goldthorpe, 'Globalisation and Social Class', West European Politics, Vol.25 No.3 (2002), p.1.

${ }^{52}$ Heinze, note 43 above.

${ }^{53}$ In DPP v. Green [2004] EWHC QB 1225, the court at first instance held that the repeated use of the word 'Paki' accompanied by several expletives did not in this case indicate racist hostility, but rather was in the context of use as a 'racial name' that appeared to mean a neutral label. The decision was criticised and overturned on appeal, although the appellate court observed, citing $R$. v. Woods [2002] EWHC 85 (Admin), that there can be cases that may have a racially neutral gravamen but nonetheless with demonstrated hostility based on the victim's membership of a racial group. The appellate court did not offer an opinion on whether the use of the word 'Paki' was capable of falling under this heading.

${ }^{54}$ Explanatory Memorandum to Criminal Justice (No. 2) (Northern Ireland) Order 2004, SI 2004 No. 1991 (N.I. 15), 2004, HMSO, at paras.2 and 3.

${ }^{55}$ Sam Dick, Homophobic Hate Crime: The Gay British Crime Survey 2008 (London: Stonewall, 2008), available

http://www.stonewall.org.uk/documents/homophobic hate crime final report.pdf (last accessed at 19 September 2008).

${ }^{56}$ Ibid., at p.31.

${ }^{57}$ For more information, see http://www.homeoffice.gov.uk/rds/bcs-methodological.html (last accessed at 19 September 2008).

${ }^{58}$ Katy Radford, Jennifer Betts, and Malcolm Ostermeyer, Policing, Accountability and the Lesbian, Gay and Bisexual Community in Northern Ireland, Institute for Conflict Research (2006), at p.16, available at http://www.conflictresearch.org.uk/documents/LGB $\% 20$ book $\% 20$ complete.pdf (last accessed at 19 September 2008). See also Neil Jarman and Alex Tennant, An Acceptable Prejudice? Homophobic Violence And Harassment In Northern Ireland, Institute for Conflict Research (2003), available at

http://www.conflictresearch.org.uk/documents/ICR Homoph.pdf (last accessed at 19 September 2008).

${ }^{59}$ For a summary of early research in the United States, see Karl Pillemer, 'The Dangers of Dependency: New Findings on Domestic Violence Against the Elderly', Social Problems, Vol.33 No.2 (1985), p.146.

${ }^{60}$ See section 146 of the Criminal Justice Act 2003 (c.44), which provides for increase in sentences for aggravation related to disability or sexual orientation (see also section 145 which covers racial and religious aggravation). 
${ }^{61}$ Select Committee on Northern Ireland Affairs, Fifth Report, 'Hate Crime: The Draft Criminal Justice (Northern Ireland) Order 2004', HC 615, HMSO.

${ }^{62}$ Select Committee on Northern Ireland Affairs, Ninth Report, 'The Challenge of Diversity: Hate Crime in Northern Ireland', HC 548-I, HMSO, at para.16.

${ }^{63}$ See http://news.bbc.co.uk/1/hi/uk/7203232.stm (last accessed at 19 September 2008).

${ }^{64}$ See the United States Supreme Court decision in Chaplinsky v. New Hampshire, 315 U.S. 568 (1942), and Eric Heinze's discussion of the case in 'Viewpoint Absolutism and Hate Speech', Modern Law Review, Vol.69 (2006), p.543.

${ }^{65}$ See, e.g., Clay Calvert, 'Hate Speech and its Harms: A Communication Theory Perspective', Journal of Communication, Vol.47 No.1 (1997), p.4.

${ }^{66}$ For an interesting and exceptionally informed discussion of this in the context of health, see Nancy Krieger, 'Does Racism Harm Health?', American Journal of Public Health, Vol. 93 No.2 (2003), p.194. For a more sceptical perspective, see Larry Alexander, Is There a Right of Freedom of Expression? (New York: Cambridge University Press, 2005). Alexander concludes, at p.193, that justified legislation in this field 'will always be limited, local, and based on hunches about consequences'.

${ }^{67}$ Gündüz v. Turkey, 4 December 2003, Application No. 35071/97, 41 EHRR 59, at para.40.

${ }^{68}$ Heinze, note 43 above.

${ }^{69}$ Readers will probably be familiar with the case of Jersild v. Denmark, (A/298) (1995) 19 EHRR 1, where broadcast of foul racist remarks about black people was held by the European Court of Human Rights to be in the light of all the circumstances justified.

${ }^{70}$ See the 2008 example of a shadow government spokesperson using the phrase 'nigger in the woodpile' (it appears that this was not simply an uncharacteristic slip):

http://www.timesonline.co.uk/tol/news/politics/article4297283.ece (last accessed at 19 September 2008).

${ }^{71}$ The point was repeatedly made during parliamentary debates: for a list of the many occasions on which the Bill was debated (it covered several topics other than the incitement offence), see http://services.parliament.uk/bills/2007-08/criminaljusticeandimmigration.html (last accessed at 19 September 2008).

${ }^{72}$ Goodall, note 34 above, at pp.112-113. Indeed, Helen Fenwick and Gavin Phillipson have argued that these restrictions are 'a strong and welcome contrast' to the potential breadth of the law on racial hatred: Media Freedom, Offence, Morality and Hate Speech (Oxford: Oxford University Press, 2006), at p.516.

${ }^{73}$ Between 1988 and 2007, there were 84 prosecutions and 60 convictions: Parliamentary Joint Committee on Human Rights, Fifth Report (2008), HMSO, Appendix 2, at para.10. See also Peter Thornton, Public Order Law (London: Gaunt, 1987), at p.61.

${ }^{74}$ Donncha O'Carroll, Legal Study on Homophobia and Discrimination on Grounds of Sexual Orientation - Ireland, European Union Agency for Fundamental Rights 2008, at para.33, available at http://fra.europa.eu/fra/material/pub/comparativestudy/FRA-hdgso-NR IE.pdf (last accessed at 19 September 2008). The study deals only with the period of 2000-2005, but there is no information suggesting any prosecution before or since.

${ }^{75}$ John O’Donoghue, Minister for Justice, Equality and Law Reform, Dáil Debates, Vol.541, 3 October 2001, at pp.60-61.

${ }^{76}$ See Donncha O'Carroll, Legal Study on Homophobia, and also the citation there of Patricia M. Leopold, 'Incitement to Hatred - The History of a Controversial Criminal Offence', Public Law [1977], p.389 at pp.401-402. Leopold argues that the absence of prosecutions in Northern Ireland during the period when its racial hatred laws required specific intent was not due to the wording of the statute but because 'a Northern Irish jury was unable to be objective about a case of incitement'.

${ }^{77}$ Northern Ireland Affairs Committee, Inquiry into Hate Crime in Northern Ireland (2004), at p.6. 
${ }^{78}$ [2002] $1 \mathrm{AC} 462$ at 475. Consider also of course the extensive European Convention on Human Rights jurisprudence on interference with rights in accordance with law.

${ }^{79}$ S.H. Bailey, D. Harris and D.C. Ormerod, Bailey, Harris \&o Jones Civil Liberties: Cases and Materials, $5^{\text {th }}$ ed. (London: Butterworths, 2001), at p.1156. See also Anthony Lester and Geoffrey Bindman, Race and Law (London: Penguin, 1972), at p.371.

${ }^{80}$ Philip N.S. Rumney, 'The British Experience of Racist Hate Speech Regulation: A Lesson for First Amendment Absolutists?', Common Law World Review, Vol. 32 No.2 (2003), p.117.

${ }^{81}$ Geoffrey Bindman, 'Inciting Hatred', New Law Journal, Vol.157 (2007), p.1086.

${ }^{82}$ Kerry Moore, Paul Mason, and Justin Lewis, Images of Islam in the UK: The Representation of British Muslims in the National Print News Media, 2000-2008, Cardiff School of Journalism, Media and Cultural Studies (2008), available at http://www.cardiff.ac.uk/jomec/resources/08channel4dispatches.pdf (last accessed at 19 September 2008).

83 Peter Oborne, The Independent, 7 July 2008, available at http://www.independent.co.uk/news/media/the-shameful-islamophobia-at-the-heart-ofbritains-press-861096.html (last accessed at 19 September 2008).

${ }^{84}$ United Nations Committee on the Elimination of Racial Discrimination, Concluding Observations of the Committee on the Elimination of Racial Discrimination, CERD/C/63/CO/11, 10 December 2003.

${ }^{85}$ JCHR, Tenth Report, March 2007, at para.366.

${ }^{86}$ Chris Frost, 'The Press Complaints Commission: A Study of Ten Years of Adjudications on Press Complaints', Journalism Studies, Vol.5 No.1 (2004), p.101 at pp.111-112.

${ }^{87}$ R. v. El-Faisal, [2004] All ER (D) 107, and R. v. Hamza, 7 February 2006 (unreported): see Simon Freeman, The Times, 7 February 2006. As the defendants also exhorted followers to kill or inflict violence on Jews and others, both were convicted of incitement to murder as well.

${ }^{88}$ R. v. Griffin and Collett, 2 February 2006 (unreported): see The Guardian, 2 February 2006. The defendants were acquitted. Video extracts from BBC recordings of the speeches, in which Griffin said among other things 'any woman that they can take by force or guile is theirs', available at http://news.bbc.co.uk/1/hi/england/bradford/6135060.stm (last accessed at 19 September 2008).

${ }^{89}$ P.F. v. Wilson (Sheriff Court) 24 October 2002 (unreported) (my thanks to the Crown Office for providing a copy of the Sheriff's decision).

${ }^{90}$ R. v. Saleem, R. v. Mubid, R. v. Javed, 2007 WL 3130840, [2007] EWCA Crim 2692, [2007] All ER (D) 462.

${ }^{91}$ Nick Davies, Flat Earth News (London: Chatto \& Windus, 2008), 374.

${ }^{92}$ Frost, note 86 above.

${ }^{93}$ See, e.g., Kühnen v. Federal Republic of Germany, 12 May 1988, Application No. 12194/86, (1988) 56 DR 205, where the European Commission of Human Rights stated that the freedom of expression in Article 10 could not be relied upon in order to carry out activities that were aimed at the destruction of other Convention rights as prevented by Article 17.

${ }^{94}$ [2004] EWHC 69 (Admin), [2004] All ER (D) 50.

${ }^{95}$ See http://www.christian.org.uk/rel liberties/cases/harry hammond.htm (last accessed at 17 September 2008).

${ }^{96}$ R. v. Saleem, R. v. Mubid, R. v. Javed, 2007 WL 3130840, [2007] EWCA Crim 2692, [2007] All ER (D) 462.

${ }^{97}$ In 2005, Danish newspaper Jyllands-Posten published several cartoons depicting the prophet Mohammed. Such depictions offended Muslims greatly, and the paper justified their publication as a contribution to debate about censorship. Reaction to the cartoons (which was intensified by the malicious circulation of more extreme cartoons, in the pretence that they had been published by the same paper) led to Muslim protests worldwide, resulting in arsons and deaths.

98 Saleem, note 96 above, at paras.45-47. 
${ }^{99}$ Larry Grant, 'Incitement to Disaffection', Index on Censorship, Vol.3 No.3 (1974), p.3. There are many good works on the broader topic of suppression of freedoms of expression and association in this context, such as the decades of writings by Keith Ewing, Conor Gearty, Clive Walker and many others, but a short and startling piece from that time is David R. Lowry and Robert J. Spjut, 'The European Convention and Human Rights in Northern Ireland', Case Western Reserve Journal of International Law, Vol.10 (1978), p.297.

${ }^{100}$ H.L. Deb., 7 May 2008, col.598.

${ }^{101}$ Graham Grant, 'Muslims’ Anger over SNP's Pro-Gay Stance', 21 January 2008.

102 There is a huge literature on this in social psychology in particular; for classic texts, see the work of T.A. van Dijk, and also M. Wetherell and J. Potter, Mapping the Language of Racism (London: Harvester Wheatsheaf, 1992).

${ }^{103}$ Rumney, note 80 above.

${ }^{104}$ Maleiha Malik, 'Speech Control', Index on Censorship, Vol.36 No.4 (2007), p.21.

${ }^{105}$ Maleiha Malik, 'Engaging with Extremists', International Relations, Vol.22 (2008), p.85.

${ }^{106}$ On anti-immigrant government discourse, see, e.g., Bill Dixon and David Gadd, 'Getting the Message? "New" Labour and the Criminalization of "Hate", Criminology and Criminal Justice, Vol.6 (2006), p.309 at pp.312-314; John Solomos, Race and Racism in Britain, $3^{\text {rd }}$ ed. (London: Palgrave Macmillan, 2003), chs.3 and 4.

${ }^{107}$ Serious Organised Crime and Police Bill, Liberty's briefing for second reading in the House of Lords, March 2005, at para.32. 